\title{
Modern and Contemporary Art in the Russian Museum Context
}

\author{
Marina V. Biryukova
}

Marina V. Biryukova, PhD, Doctor of cultural studies,

Saint Petersburg State University

Institute of Philosophy

Department of Museum Work and Protection of Monuments

5, Mendeleevskaya Line,

199034 Saint Petersburg,

Russia

e-mail:arsvita@mail.ru

Muzeológia a kultúrne dedičstvo, 2020, 8:3:63-74

DOI: $10.46284 / \mathrm{mkd} .2020 .8 .3 .3$

Modern and Contemporary Art in the Russian Museum Context

The article considers contemporary and modern art in Russia as reflected in museum curatorial projects. The concepts of large-scale museum exhibitions are based on certain categories that correspond to following qualities: the connection with the centuries-old tradition, myth-making, ludic aspects and internationality - openness to the perception of other cultures. The article analyses exhibition projects in the beginning of the twentieth century, in which contemporary art is demonstrated in the space of tradition, the media context, the everyday context and the context of cultural myths and symbols. The problem of determination of the aesthetic value of contemporary art is stressed in the space of the museum, and represented artworks receive a bigger expressiveness in the neighborhood of works of traditional art. Exhibition curators effectively use aesthetic and formal contrasts; sometimes classical artworks themselves suggest new ways of understanding meanings, hypothetically included in contemporary art - as seen in the projects at the Hermitage, the State Russian Museum and the State Tretyakov Gallery, where curators can unite or contrast tradition and modernity.

Keywords: contemporary art, modernism, museum, exhibition, curatorial project.

\section{Introduction}

The actualization of contemporary art in the context of a classical museum, popular in the West, has become fashionable in Russia. It is an effective practice, both from the point of view of cultural and media resonance, and from the point of view of enrichment of the context in which the artifacts of the latest trends are interpreted. Curatorial projects ensure art's eternal movement towards the museum. The idea of the "eternal return" to museums, classics, evolution, continuity of tradition, and hierarchy is immortal even in the context of the postmodern paradigm in the era of simulacra. In the words of Boris Pasternak, "What elephants do they make here out of flies?". "The ability to "make elephants out of flies" is a great achievement of modern mass culture. Contemporary art exhibitions at the Hermitage museum can serve as a kind of illustration of this statement. In the beginning of this curatorial tendency, in 2001, a huge Spider by Louise Bourgeois was shown in the Baroque space of the Great Courtyard of the Winter Palace. Later came large-scale exhibitions of Robert Mapplethorpe (Robert Mapplethorpe and the Classical Tradition: Photographs and Mannerist Prints, 8 December 2004 - 16 January 2005), Francis Bacon (Francis Bacon and the Art of the Past, 7 December 2014 - 3 August 2015)

${ }^{1}$ PASTERNAK, Boris. Ochrannaja gramota. Moscow: Sovremennik, 1989, p. 16. 


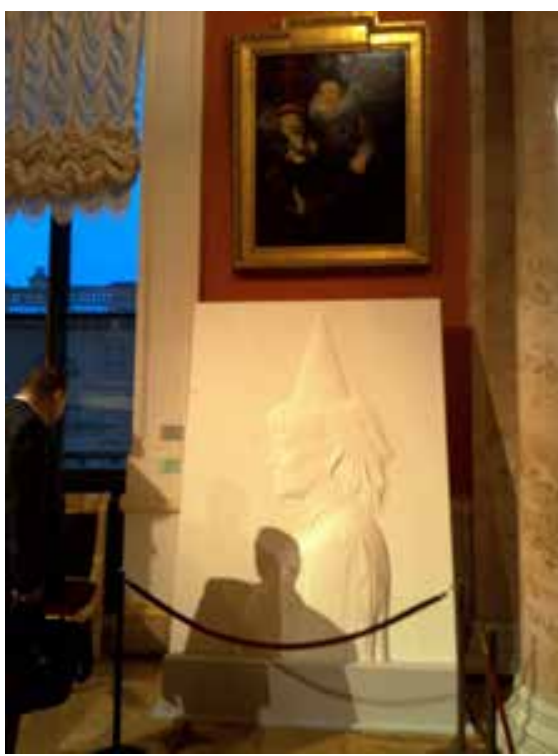

Figure 1: At the exhibition Jan Fabre: the Knight of Despair - the Warrior of Beauty, 21 October 2016 - 9 April 2017, the State Hermitage museum. The author's photo. and Jan Fabre (Jan Fabre: the Knight of Despair - the Warrior of Beauty, 21 October 2016 - 9 April 2017) in the context of classical art (Figure 1).

Russia is rapidly developing a practice of "big exhibition projects" and the programming of large-scale art exhibitions. Quite often these exhibitions include both classical and contemporary art. On 28 June 2007, in the Benois Wing of the State Russian Museum, the exhibition Adventures of the Black Square opened, dedicated to the creative reception of the famous Black Square of Kazimir Malevich. Metamorphosis of the Black Square in the interpretation of the masters of avant-garde and contemporary artists allowed the curators to demonstrate the evolution of artistic form, which at the time of its creation had been extremely innovative. The exhibition presented works from the collection of the State Russian Museum, the Hermitage, the Tretyakov Gallery, the Museum of Theatrical and Musical Art and private collections, giving viewers the opportunity to trace the development of the symbolic image of the black square. However, the idea of the exhibition lay not only in ascertaining the endless transformation of symbolic figures, but also in discovering a history of interpretation of Malevich's invention - from the first copies of Nikolai Suetin and other students of Malevich to similar experiments by Vladimir Sterligov and Vassily Kandinsky, and then to variations on the theme of contemporary artists. The fact that the exhibition was opened at the Russian Museum in the context of the tradition of national art gives it additional clarity. The problem of "citation" of the art form and its association with artforms of the past is relevant at all times, and curators of the exhibition managed to convey this idea.

One year earlier, the State Hermitage Museum organized a similar exhibition, Around the Square (23 December 2005 - 19 March 2006), from the series Christmas Gift. It was prepared with the participation of the Imperial Porcelain Factory (formerly the Lomonosov porcelain factory), which exhibited a collection of porcelain painted by artists of the Russian avant-garde. In addition to the Suprematist porcelain, works of Vassily Kandinsky, as well as Kuzma Petrov-Vodkin and other prominent figures of Russian modernism, were presented. The integrity of ideas demonstrated at the exhibition and its visual impact was due not only to the famous names of artists represented but also to the opportunity to show decorative properties of avant-garde artforms. The classical tradition of applied art and the context of the Hermitage collection have contributed to this in full. However, no less significant was the symbolic component of the exhibition; in particular, the items of "propaganda porcelain" that were included. The exhibition, curated by Tamara V. Kudryavtseva and Tatiana V. Kumzerova, demonstrated how expressive means of Futurism, Cubism and Suprematism relate to decorative shapes of porcelain and how convincingly the artists' works meet their goal to express the joy of labour and the glory of the Soviet government. The plate Earth - For Workers by Nathan Altman, and a similar product by Maria Lebedeva, He Who Does Not Work, Shall Not Eat, present actual 
slogans of the time, conveyed with the help of distinct art forms. The exhibition clearly shows the continuation of domestic traditions of both modernism and the classics.

The reflection of the main trends of the national cultural situation in museum projects results in the fact that the curators' concepts demonstrate not only the modern cultural paradigm, but also reflect the general museum policy, the curators' theoretical views and media context. Exhibitions of contemporary art are aimed at familiarizing the public with both modern trends in art and the context of heritage in the largest museums, as well as the determination of the cultural situation in general. ${ }^{2}$ Classification and reception of the significant museum exhibition projects in the field of contemporary art deserves thorough future study.

\section{Russian contemporary and modern art in the institutional context}

In the Soviet era, the art of non-conformism largely imitated Western art. But even though the non-conformists could not be significant competitors with the West in the field of the latest trends of art reflected in postmodernism, their demonstration was banned at home. In 1964, an exhibition of unofficial artists, including Mikhail Shemyakin, opened at the State Hermitage Museum, after which the Director of the museum, Mikhail I. Artamonov, was fired. On 15 September 1974, an amateur outdoor exhibition of non-conformists acquired a venue for a large-scale performance. As this event was finished with the help of police and heavy machinery, it was called The Bulldozer Exhibition.

The artist Vladimir Yankilevsky, during the Khrushchev Thaw epoch, created typically modernist works in which it is easy to find quotes or paraphrases of Pablo Picasso, Paul Klee, Fernand Leger. At a time when Western modernism was already starting to lose its expression in comparison to the latest radical trends in the spirit of anti-form, and the works of modernists quietly took their places on the walls of museums, banks and corporations, in the Soviet Union non-figurative painting still evoked strong reactions of admiration, rejection or hatred. It is now obvious that in the Sretensky Boulevard Group - a circle of unofficial artists which included Ernst Neizvestny, Ilya Kabakov, Hulot Sooster, Erik Bulatov - Vladimir Yankilevsky was probably the most "traditional" artist. He consistently continued the tradition of the prewar avant-garde in the 1960s, when his art generated the most severe critical reception and created strong abstract works, the originality of which was due to obvious erotic overtones. However, these works, which might be now perceived as ecorative and balanced (during the retrospective exhibition of the artist in Bochum, a session of collective meditation was even held in front of them), built Yankilevsky's reputation as a non-conformist. Two of them - Triptych No. 2. Two principles and the pentaptych Atomic Station were shown at a special "informal" part of the exhibition 30 Years of MOSKh at the Manege which opened on 1 December 1962. The artists who first saw their work on the walls of the large hall did not suspect that the possibility of their participating in the exhibition had been a provocation. Well-established masters of the Union of Artists wished to discredit the left wing of the MOSKh by demonstrating a row of independent artists' works as degenerate specimens of the new art. This section of the exhibition

\footnotetext{
${ }^{2}$ ALTSHULER, Bruce. Biennials and Beyond: Exbibitions That Made Art History 1962-2002. New York: Phaidon, 2013; BAETSCHMANN, Oskar. The Artist in the Modern World. Cologne: DuMont, 1997; MACDONALD, Sharon - BASU, Paul (eds). Exbibition experiments. London: John Wiley \& Sons, 2008; BIRYUKOVA, Marina. The Philosophy of Curatorship. St Petersburg: Dmitry Bulanin, 2018; VANDERLINDEN, Barbara - FILIPOVIC, Elena (eds). The Manifesta decade: debates on contemporary art exhibitions and biennials in post-wall Europe. Cambridge, MA: MIT Press, 2005; O’NEILL, Paul. The Culture of Curating and the Curating of Culture(s). Cambridge, MA: MIT Press, 2012; GREENBERG, Reesa - FERGUSON, Bruce - NAIRNE, Sandy. Thinking about exhibitions. London and New York: Routledge, 1996.
} 
was not shown to the public, and the government delegation led by Khrushchev had spoken quite rudely about the artworks presented therein. Vladimir Yankilevsky, who managed to have a chat with the General Secretary, quickly realized that they spoke different languages, in the cultural sense, as he later mentioned in the book And two figures... Their dialogue was as follows:

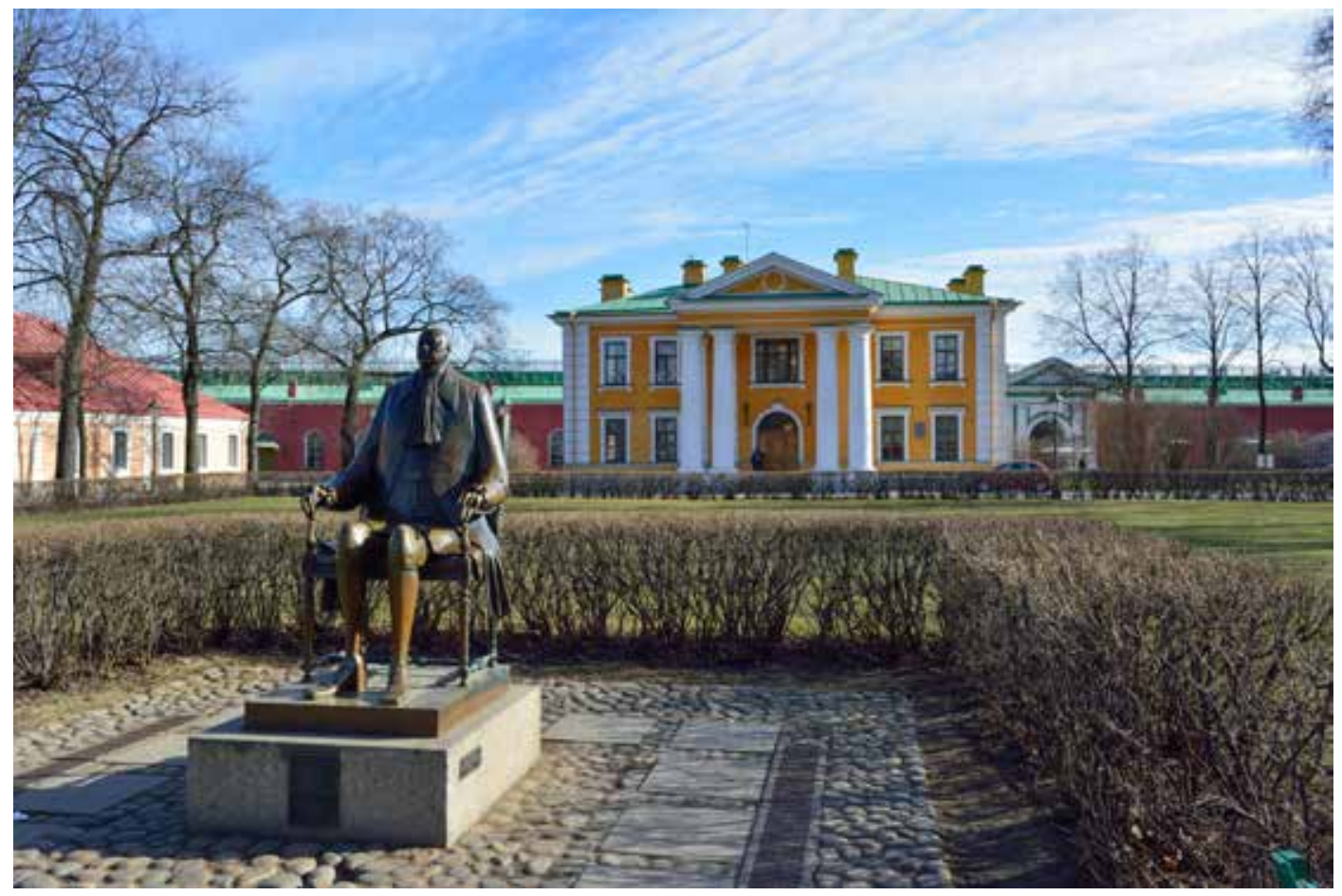

Figure 2: The monument to Peter the Great by Mikhail Shemyakin in the Peter and Paul fortress, St. Petersburg. Photo: Anton Shestakov. (https:// commons.wikimedia.org)

"- What is it? - asked Khrushchev.

- It is a pentaptych Atomic Station.

- No, - he said, - it's a scribble.

- No, it's the pentaptych Atomic Station.

- No, it's a scribble."3

On this cheerful note ended the dialogue between the artist and the power, and it was the beginning of a usual life of a Soviet non-conformist.

In the 1980s, the members of Timur Novikov's circle organized the so-called Apartment Exhibitions in private flats to show their art. Only in the perestroika period did the artists have the opportunity to openly compare their works with the works of their Western colleagues.

What is happening now? For comparison, Mikhail Shemyakin is working on several major projects in Russia: in particular, a monument to Peter the Great which is standing in the Peter and Paul Fortress (Figure 2), and the design for a performance of The Nutcracker at the Mariinsky Theater. He opened his Fund and Art Center in St Petersburg with a permanent exhibition of his works. At the State Russian Museum in the Ludwig Museum in the Marble Palace, a large-scale exhibition of Vladimir Yankylevsky Moment of Eternity (12 July 2007 - 31 August

${ }^{3}$ JANKILEVSKY, Vladimir. I dve figuri... Moscow: NLO, 2003, p. 128 
2007) took place and a major exhibition Ilya and Emilia Kabakov: "The Incident in the Museum" and Other Installations (22 June 2004 - 29 August 2004) presented the works of Ilya Kabakov at the Hermitage. Kabakov had left Russia during the Soviet period.

In recent years, a series of competitive projects have appeared similar in scope to the largest exhibitions such as the Venice Biennale or documenta in Kassel. One such example is the Moscow Biennale of Contemporary Art. Many of its projects take place in museums. Contemporary Russian culture in the institutional context is analyzed, for example, by Mikhail Epstein. ${ }^{4}$ Russian art theoretician and curator Viktor Misiano notes that "to demonstrate Russian art at the world centers and uphold Western standards in the Russian context today is a priority direction of artistic policy". 5

The first Moscow Biennale of Contemporary Art took place in 2005 in the A. S. Pushkin State Museum of Fine Arts, the Tretyakov Gallery, MMoMA (Moscow Museum of Modern Art), the Central House of Artists, the former Vladimir Lenin Museum, Vorobiyevy Gory metro station and other venues. The Commissioner of the Biennale was Evgeny Zyablov and the curators were Joseph Backstein, Daniel Birnbaum, Yaroslava Bubnova, Nicolas Bourriaud, Rosa Martinez and Hans Ulrich Obrist. The theme was "Dialectics of Hope". Associated with the main theme were theoretical works by Boris Kagarlitsky. Among the invited artists were Christian Boltanski, Bill Viola and Ilya Kabakov.

In 2017, the main exposition of the Seventh Moscow Biennale of Contemporary Art was displayed in the State Tretyakov gallery. The main venues for the parallel program were MMoMA, the Multimedia Art Museum, the Winzavod centre of contemporary art, the Darwin Museum and Moscow State University Botanical Garden, among others. It was curated by Yuko Hasegawa, Artistic Director of the Museum of Contemporary Art, Tokyo, and supported by the Ministry of Culture of the Russian Federation, showing artworks by 52 artists from 25 countries. Among the participants were Matthew Barney, Olafur Eliasson and Björk.

In the last decade, philosophical thought in the West has been trying to compensate for the lack of hierarchical criteria, a characteristic of postmodernism, and to identify ways of overcoming the postmodern paradigm, noting its exhaustion. Researchers of the beginning $f$ the twenty-first century pay attention to the possibility of a new metaphysical context of the era, new "big ideas" and meta-narratives. Some theorists propose the replacement of postmodernism with metamodernism or post-postmodernism, ${ }^{6}$ based on the reincarnation of totally symbolic narratives subjected to deconstruction in postmodernism but in the context of the openness of the information society and with a possibility of continuing interpretations of certain global truths. In exhibition practice, these intentions are reflected in the emergence of curatorial projects based on global themes. The global issue of the day might, for example, become a new look at the human body as a source of creativity, but not with the purpose of achieving perfection and not with the opposite intention - of mortification and asceticism (these two intentions have competed throughout the history of mankind). A new aspect of attitude to the body implies its consideration as an art material - the possibility of creation of an original artefact through metamorphosis associated with tattoos, plastic surgery, piercings, scarification, etc. Aesthetic characteristics of the process, as in art, have ceased to play a de-

\footnotetext{
${ }^{4}$ EPSTEIN, Mikhail. After the future: The paradoxes of postmodernism and contemporary Russian culture. Amherst, MA: University of Massachusetts Press, 1995.

${ }^{5}$ MISIANO, Viktor. Piat leczii o kuratorsrve. Moscow: Ad Marginem, 2014, p. 194.

${ }^{6}$ VERMEULEN, Timotheus - VAN DEN AKKER, Robin. Notes on metamodernism. In: Journal of Aesthetics and Culture, 2, 2010, pp. 2-14.
} 
cisive role here. In philosophy, this topic began to attract researchers as a reason for thinking about the relationship between mind and body. ${ }^{7}$ In the exhibition sphere it is reflected in a series of exhibitions dedicated to the metamorphosis of the body and image: for example, the extremely popular exhibitions of contemporary mummies by Gunther von Hagens in Europe; or in Russia, the reincarnation performances of Arts Vlad Mamyshev-Monroe, a member of the New Academy of Fine. Another example from Russia is the exhibition Tanatos Banionis. Divine Wind at the Marble Palace of the State Russian Museum (4 September 2010 - 26 September 2010) curated by Dmitry Hankin, for which the bodies of several participating girls were covered with intricate tattoos. This trend illustrates a certain commonality between the Western and Russian art situation - the state of exhaustion of artistic form and the symbolic end of art, when denial of the artform comes to an absolute state, and artists can do nothing but experiment with their own or someone else's body. This tradition, starting with Viennese actionists, has been continued in Russia by Petr Pavlensky, who sewed up his mouth in front of the Kazan Cathedral in a work of performance art to support the members of Pussy Riot group on 23 July 2012.

New trends in philosophy are a logical continuation of the evolution of twentieth-century philosophical thought, a way of overcoming the postmodern paradigm. They are also relevant to contemporary Russian culture and its impact in the world.

The symbolic component, as in the Soviet era, is strong in Russian art. It is demonstrated by a series of exhibitions dedicated to symbols, allegories and symbolic figures. Here the native tradition is also close to the West, as contemporary art here would be inconceivable without an idea or concept beyond a significant symbolic and allegorical dimension.

In Western culture, for example, a consistent evolution of exhibition concepts can be traced on the subject of "nothing" - exhibitions without artworks, or with the demonstration of anti-form. The content is logically connected to the postmodernist paradigm of emptiness. On 25 February 2009, a large-scale exhibition, Vides: Une Retrospective, opened at the Centre Pompidou in Paris, bringing together several conceptions of emptiness, from the remake of Yves Klein's first "empty exhibition" to the project Air Conditioning from the group Art \& Language. The participating projects demonstrated between them a variety of forms of "emptiness".

Analogously, in Russia several projects were organized showing the same tendency. The experience of "emptiness" was reflected in the exposition prepared by the State Tretyakov Gallery for its participation in the Fourth Moscow International Biennale of Contemporary Art in 2011: a project called Hostages of Emptiness. The aesthetics of "empty space" and "void canon" in the Russian art of the nineteenth and twentieth centuries was reflected here. The theme of "emptiness" and "nothingness", based on either the sacred feeling of emptiness or the rejection of traditional artistic forms in contemporary art, shows the desire of many artists to move towards the "zero points" of art. The objective of the project was to show the evolution of the concept of "void" in Russian art and to find the origins of the "void canon" in literature and philosophy. The exhibition was a result of thinking about the lack of clear criteria for defining what is contemporary art, beyond tradition. The relevant example of the cultural battle between tradition and the art of today in the obvious anti-institutional and anti-museal context was demonstrated the project Empty Zones by Andrei Monastirsky and Collective Actions at the

\footnotetext{
${ }^{7}$ JOHNSON, Mark. The meaning of the body: Aesthetics of human understanding. Chicago: University of Chicago Press, 2007; SHUSTERMAN, Richard. Body Consciousness. A Philosopby of Mindfulness and Somaesthetics. Cambridge: Cambridge University Press, 2008; SWEETMAN, Paul. Anchoring the (postmodern) self? Body modification, fashion and identity. In: Body and Society, 5, pp. 51-76, 1999.
} 
54th Venice Biennale (4 June - 27 November 2011).

Metamorphosis of traditional myths, particularly the myths of the Soviet epoch, was shown through museum exhibitions dedicated to the Revolution of 1917. Bearing in mind an ambiguous attitude to revolution in society, one might be surprised by the large scale of the relevant projects. The centenary of the October Revolution gave the major museums the opportunity to consider this topic in original curatorial projects.

On 29 September 2017, the State Tretyakov Gallery opened the exhibition Someone 1917, where artworks created in 1917 by Boris Kustodiev, Mikhail Nesterov, Kuzma Petrov-Vodkin, Vasily Kandinsky, Kazimir Malevich and others were presented. Most of these works did not reflect the revolutionary events, and the exhibition was divided into thematic sections: Myths of the people, City and citizens, Faces, Away from this reality!, Vague, The Utopia of the new world, Chagall and the Jewish question. For this large-scale project, works were drawn from the collections of the Tretyakov Gallery and the Russian Museum, Centre Georges Pompidou, the Tate Modern Gallery, the Ludwig Museum, the Tel Aviv Museum of Art and archives of Moscow and St Petersburg.

In the New Tretyakov Gallery on Krymsky Val, the exhibition The Wind of Revolution (29 September 2017 - 25 March 2018) was dedicated to the sculpture in 1918-1932.

At the Russian Museum, the exhibition Art into Life! (17 August 2017 - 27 November 2017)

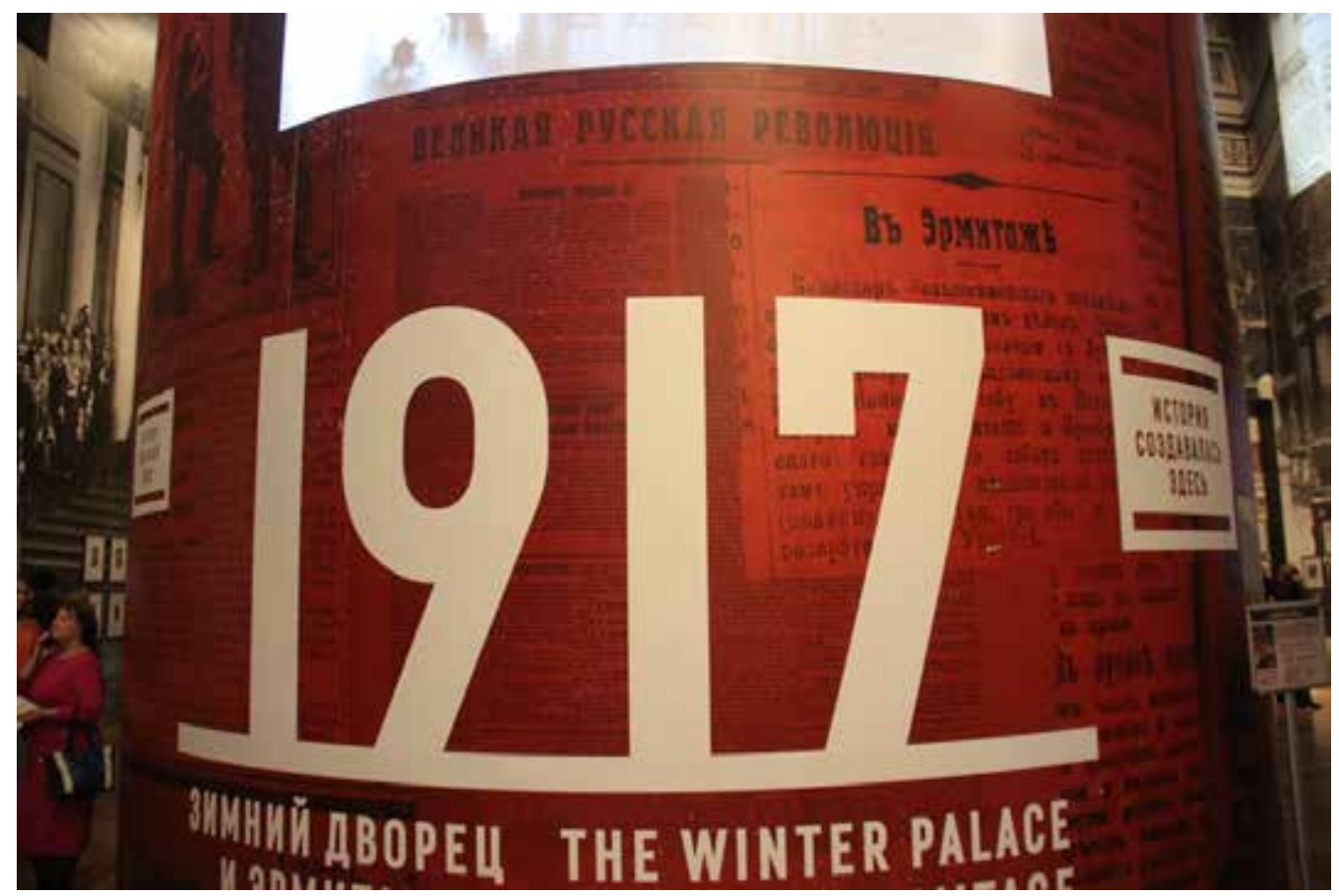

Figure 3: The exbibition The Winter Palace and the Hermitage in 1917 at the State Hermitage Museum. Photo: Andrey Filippov. (https://commons.wikimedia.org)

presented propaganda porcelain of the Decorative Institute in Petrograd-Leningrad, with pictures of a new Soviet way of life after the revolution.

The exhibition The Winter Palace and the Hermitage in 1917 (26 October 2017 - 4 February 2018) at the State Hermitage Museum presented the main events of the February Revolution, the abdication of Nicholas II and the October Revolution through the eyes of those who re- 
mained in the museum in 1917 (Figure 3).

One omission is that there was no significant exhibition dedicated to the anniversary of the abolition of serfdom in 2011. This anniversary has gone unmarked.

\section{International contemporary art in Russian museum projects}

Russia is rapidly entering the international art scene. European and American contemporary art is often on display in the biggest museums of Russia in the projects organized by teams of Russian and Western curators. Early in the twenty-first century, several exhibitions at the State Hermitage Museum were organized, reflecting to varying degrees the difficult relationship between contemporary art and tradition, modern artifacts and the space of the classical museum. The following exhibitions were large projects of the new Department of the Museum - Hermitage 20/21: America Today, The Choice of Charles Saatchi (24 October 2007 - 17 January 2008) in the General Staff building of the Hermitage, presenting American art; New Language - British Art Today (25 October 2009 - 17 January 2010), curated by Dmitry Ozerkov, which continued cooperation between Hermitage 20/21 and the Saatchi Gallery; and Manifesta10, which opened on 28 June 2014 and was curated by Kasper Koenig.

An important role in contemporary exhibition projects is played by the aspect of hidden text or hidden narrative that refers to obvious cultural realities. For example, in Manifesta 10, on display in the rocaille boudoir of the Empress Maria Alexandrovna was a shell sculpture made by Katharina Fritsch, entitled Woman with Dog (2008) - the title of which was an obvious

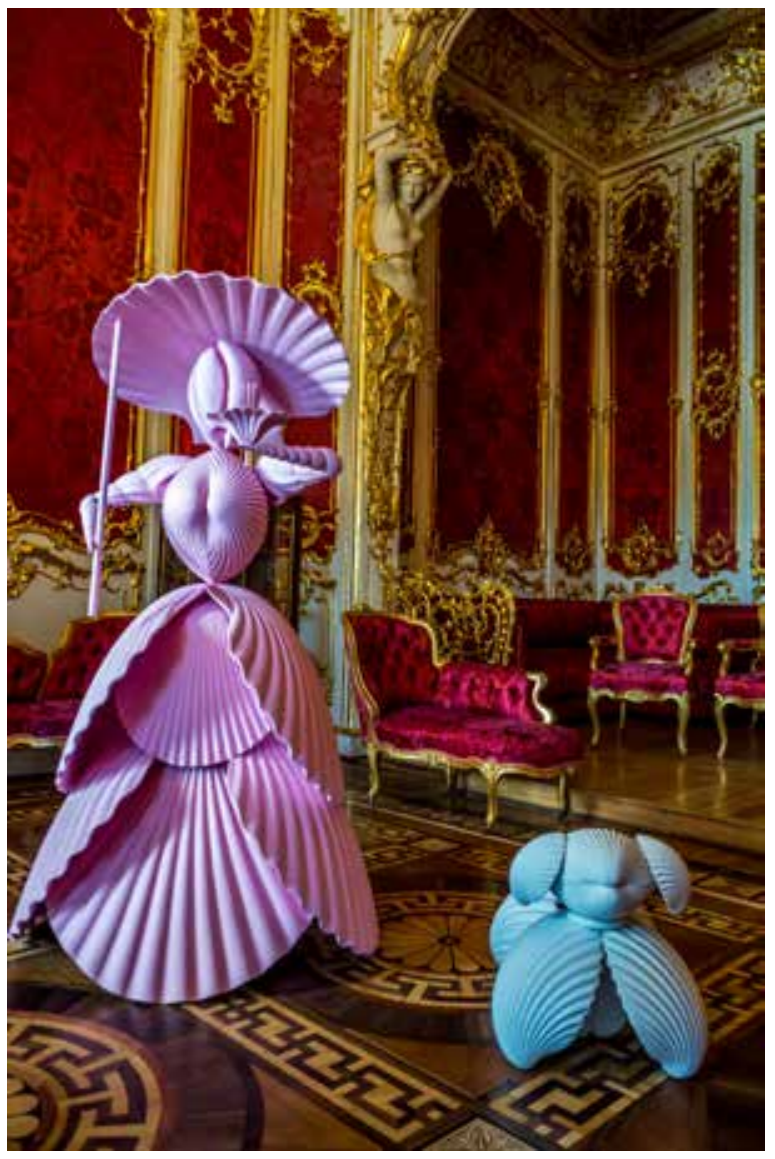
allusion to Anton P. Chekhov's famous story The Lady with the Dog. The hidden text here enabled the viewer to repeat the story, facilitating a dialogue of contemporary artworks with the interior of the mid-nineteenth century, the time of the return of Rococo, hypothetically moving the object of K. Fritsch to this era (Figure 4). The creation of myths is, undoubtedly, one of the main characteristics of the contemporary artistic process. Any large exhibition project is accompanied by the creation of media myths. The exhibition project can be seen as a narrative of an artist, a curator or a critic. To understand and interpret a large exhibition, we require a certain context which may take the form of a narrative consisting of ideas and meanings of works of art. The symbolic meaning of Thomas Hirschhorn's The Cut (2014), presented in the General Staff Building, certainly

Figure 4: Katharina Fritsch, Woman with Dog (2008) at the Manifesta 10 (2014). Photo: sergejf. (https:// commons.wikimedia.org 
made it a central piece of Manifesta 10. An impressive installation, it filled with a spirit of catastrophe; it looked like a ruined house with damaged walls, fragments of which were poured directly into the hall. Through gaping window openings, post-disaster household items were visible, among which one could see pictures hanging on the surviving walls. The viewer did not immediately realize that they were originals of famous works of twentieth-century Russian art from Kazimir Malevich to Pavel Filonov, taken from the Russian Museum. According to the art critic Elisaveta Shagina,

A cultural cut is the point that opens the movement back to basics, to the avant-garde of the early 20th century, from which modern art began. The artwork speaks about the chasm that separates us from the avant-garde, and 'we' here are, of course, Western artists and Russian artists. We are accustomed to be seen counterfeiting but before the face of the past, we are equal and united... Classical art and avant-garde, the collapsed utopia and a new history stare at each other with fear, but ready to start a conversation. I think for this historic cut the whole Manifesta 10 has started. ${ }^{8}$

The installation The Handkerchiefs' Opera by Dominique Gonzalez-Foerster in the General Staff Building also appealed to the classics of modern art. Reproductions of famous works, including those by Malevich, placed on huge "handkerchiefs", posed a question about the justification for replicating "masterpieces", the images of which haunt people in the most unexpected areas of consumer culture - from advertising to fashion accessories. The juxtaposition of banality and everyday life (because what could be more banal than a handkerchief!) and elite art is the main intention of this work. A bold expansion of everyday life in culture and culture in everyday life was far more effective for understanding new trends than many hours of lectures about art would have been for the Russian and Western public at the exhibition. Contemporary art presented at Manifesta 10 suggested not only a metaphysical dialogue but a very specific physical confrontation between modernity and tradition. An especially distinct means of 'destruction' of the museum space was realized in Francis Alÿs's project, Lada Kopei$k_{a}$, in the Grand Courtyard of the Winter Palace, representing a broken Soviet car at the end of its difficult journey from Belgium (the native country of the artist) to St Petersburg. This project was complemented by documentation of the journey, which was also demonstrated in the museum. Combining Russian-Soviet realities and postmodern attitudes to art, Lada Kopeika was a remarkable sample of interaction between Russian and European culture.

Ekaterina Degot speaks about the contradiction of the non-profit art event Manifesta 10 and the undoubted aura of the art market which exists in the major museum which inevitably adds value to artworks exhibited there:

The Hermitage, with its intention to show 'high art' and precious collections, plays here a special role. The museum, the identity of which has always been based on gold (of scythians or kings), has always been special and in a certain sense, it resisted the status of typical Soviet museums with documents and ideological paintings, museum didactic and anti-fetish nature. In the Soviet culture,

\footnotetext{
${ }^{8}$ SHAGINA, Elisaveta. Manifesta 10. Accessed 10 May 2019, http://salonn.ru/article/898-manifesta10-ot-velikogo-doaktualnogo/.
} 
the Hermitage, together with other St. Petersburg palaces, was a rare area of 'rhetoric of wealth', which, according to a conservative logic, linked the public mind with the area of "high art".

The general public, on the contrary, sees in the curatorial project of Manifesta 10 the messenger of valuable democratic ideas, even in the banal form of "adding value" to the art displayed within the walls of the Hermitage. Nor can one overlook the ambiguous and sometimes negative reaction of the general audience to Manifesta 10, despite considerable attendance at the exhibition. Among the negative aspects of Manifesta 10's reception were harsh comments from Biennale spectators, the public's unbridled desire to have fun instead understanding the artworks, and the barbaric treatment of parts of Thomas Hirschhorn's installation. But, apparently, the interactivity of the Biennale generated by the curatorial staff made such a reaction inevitable, given the experience was not characteristic of an ordinary visit to the classical museum.

The myths of the artists and curators in the "big project" combining Russian, Western and global aspects became a meta-language or a code to help the visitor to understand the modern paradigm of art in connection with:

- Exchange of information in the field of art

- Emphasis on social and cultural experience of the viewer

- Increasing the attractiveness of the exhibition project

- Appeal to a broader audience

The creation of a new Russian national myth is impossible without the involvement of key charismatic figures - from Peter the Great to Kazimir Malevich. Mythological consciousness plays a significant role in contemporary culture. One can see how intensively modifications of traditional myths are reproduced, and how easily new media myths-for-one-day are being created. The theme of myths and mythology attracts much attention from curators of contemporary art, and Manifesta 10 demonstrated it distinctly. Manifesta 10 has the main features of a total artwork: a concept, qualities of performativity, imitation of reality, visual technologies and effects, and a significant media response. This is an interesting example of Gesamtkunstwerk, the term analysed in the book Gesamtkunstwerk Stalin by Boris Groys, in which the era of Stalin is appraiseded in the context of the "total artwork". ${ }^{10}$ The basis of the last concept was laid by Richard Wagner in the essay The Artwork of the Future. ${ }^{11}$ Wagner uses the term Gesamtkunstwerk to describe the ideal state of art as a synthesis of all kinds of art in the theatre. The post-Wagnerian concept of the total artwork implies not only the synthesis of the arts but also the features of a single artistic and metaphysical entity which might as well be called a narrative, referring to social, political and philosophical realities, cultural traditions and media.

The idea was subsequently continued in contemporary cultural studies in relation to interactivity within contemporary art. The artist Ilya Kabakov later used the term total installation. In his lectures on contemporary art in Frankfurt am Main (1992), the artist said that the audience was the centre of the total installation. But the audience in modern Russia varies considerably according to individuals' social, educational and ideological backgrounds. Obviously, an experiment of the Gesamtkunstwerk type is possible in modern Russian culture only in the context of a single exhibition project. Stylistic unity in the official culture, as in the Stalin era, does not exist.

\footnotetext{
${ }_{9}^{9}$ DEGOT, Ekaterina. Text, kotory pisat ne sledovalo? Accessed 10 May 2019, http://www.colta.ru/articles/art/3702

${ }^{10}$ GROYS, Boris. Gesamtkunstwerk Stalin. München: Carl Hanser, 1988.

${ }^{11}$ WAGNER, Richard. Das Kunstwerk der Zukunft. Leipzig: Wigand, 1850.
} 


\section{Conclusion}

Symbols of national culture are exposed to modern revision in the context of contemporary exhibition projects. In conceptually sound curatorial projects, it is possible to determine categories linking modernity with tradition, as can be seen, for instance, in the exhibition Gates and Doors that was held in the Russian Museum (28 April 2011 - 20 June 2011), which combined both the principles of ludic culture and a feeling of continuous tradition. The exhibition demonstrated the possibility of a broad interpretation of gates and doors as symbols - as essential, iconic images in culture and art. The concept of the exhibition covered a significant period - from the sacralization of gate symbols in ancient art to the metamorphosis of this image in contemporary art. The art of the latest trends in this case does not diminish but adds a new emphasis to the symbolism of doors. Works by Ilya Kabakov, Oleg Kulik, Sergey Bugaev (Africa) and other contemporary artists, placed in the context of tradition, symbolized a kind of transition and the destruction of barriers between the present and the spiritual past. The possibility of such a comparison is a benefit of large-scale thematic exhibitions united by a common motive or idea. Such projects play a significant role in the modern development of tradition in Russia and, at the same time, are components of postmodern art.

Other Russian curatorial projects are relevant to Western art theory and aesthetic concepts such as the "death of art" of Arthur Danto, or the "death of the author" of Roland Barthes, though with a significant temporal distance. For example, in the project by Ekaterina Degot and Yuri Albert What Did the Artist Mean by That? (22 November 2013 - 12 January 2014) at the Moscow Museum of Modern Art, illustrated the actual cultural situation in which context and interpretation displace, and can even completely erase from our consciousness, an impression of an artist's work, making it redundant and irrelevant. At the opening of the exhibition, only comments on and captions to objects were presented, not the artworks themselves. The artefacts took their places gradually until the closing day of the exhibition. If the object had "materialized" at the exhibition, the caption disappeared in turn. This exhibition is analogous to the media and ideological vacuum, where genuine visual images or real facts do not necessarily exist, only symbolic references to them or an extensive interpretation.

It is obvious that it is not an easy task for a museum curator to make a contemporary art project in the institutional context. Perhaps the boundaries of modernity and tradition set by the space of the museum, show more distinctly the contradictions of the past and the present in a holistic exhibition project. The context of the museum requires for its perception certain efforts or mental tasks that are absent from the entertainment cultural industry in a consumer society.

\section{References}

ALTSHULER, Bruce (2013). Biennials and Beyond: Exhibitions That Made Art History 1962-2002. New York: Phaidon. ISBN 978-0-7148-6495-2

BAETSCHMANN, Oskar (1997). The Artist in the Modern World. Kologne: DuMont. ISBN 0-300-07323-2

BIRYUKOVA, Marina (2018). The Philosophy of Curatorship. St Petersburg: Dmitry Bulanin. ISBN 978-5-86007-872-7

EPSTEIN, Mikhail (1995). After the future: The paradoxes of postmodernism and contemporary Russian culture. Amherst, MA: University of Massachusetts Press. ISBN 978-0-8702-3974-8 
GREENBERG, Reesa, FERGUSON, Bruce - NAIRNE, Sandy (1996). Thinking about exbibitions. London and New York: Routledge. ISBN 978-0-4151-1590-2

GROYS, Boris (1988). Gesamtkunstwerk Stalin. München: Carl Hanser. ISBN 3-446-15321-7

JANKILEVSKY, Vladimir (2003). I dve figuri... [And Two Figures...]. Moscow: NLO. ISBN 5-86793-242-7 [in Russian]

JOHNSON, Mark (2007). The meaning of the body: Aesthetics of human understanding. Chicago: University of Chicago Press. ISBN 978-0-2264-0192-8

O'NEILL, Paul (2012). The Culture of Curating and the Curating of Culture(s). Cambridge, MA: MIT Press. ISBN 978-0-2625-2974-7

MACDONALD, Sharon - BASU, Paul (eds) (2008). Exhibition experiments. London: John Wiley \& Sons. ISBN 978-1-4051-3076-9

MISIANO, Viktor (2014). Piat leczii o kuratorsrve [Fife Lectures on Curating]. Moscow: Ad Marginem. ISBN 978-5-91103-237-1 [in Russian]

PASTERNAK, Boris (1989). Ochrannaja gramota [Charter of Immunity]. Moscow: Sovremennik. ISBN 5-270-01061-5 [in Russian]

SHUSTERMAN, Richard (2008). Body Consciousness: A Philosophy of Mindfulness and Somaesthetics. Cambridge: Cambridge University Press. ISBN 978-0-5216-7587-1

SWEETMAN, Paul (1999). Anchoring the (postmodern) self? Body modification, fashion and identity. In: Body and Society, 5, pp. 51-76. ISSN 1460-3632

VANDERLINDEN, Barbara, FILIPOVIC Elena (eds) (2005). The Manifesta decade: debates on contemporary art exhibitions and biennials in post-wall Europe. Cambridge, MA: MIT Press. ISBN 978-0-2622-2076-7

VERMEULEN, Timotheus - VAN DEN AKKER, Robin (2010) Notes on metamodernism. In: Journal of Aesthetics and Culture, 2, pp. 2-14. ISSN 2000-4214

WAGNER, Richard (1850). Das Kunstwerk der Zukunft. Leipzig: Wigand.

Internet sources

DEGOT, Ekaterina (2014). Text, kotory pisat ne sledovalo? [The Text Which Should Not Be Written?]. Accessed 10 May 2019, http://www.colta.ru/articles/art/3702 [in Russian]

SHAGINA, Elisaveta. (2014). Manifesta 10. Accessed 10 May 2019, http://salonn.ru/article/898-manifesta10-ot-velikogo-doaktualnogo/ 